\begin{tabular}{|c|c|}
\hline $\mathrm{M} \mathbf{R} \boldsymbol{R}$ & Management and Business Review \\
\hline $\begin{array}{l}\text { MANAGEMENT \& } \\
\text { BUSINESS REVIEW } \\
\end{array}$ & $\begin{array}{c}\text { Available at } \frac{\text { http://ejournal.unikama.ac.id/index.php/mbr }}{\text { ISSN: } 2541-5808 \text { (online) }}\end{array}$ \\
\hline
\end{tabular}

\title{
Menganalisis permasalahan kredit macet pada Koperasi Simpan Pinjam
}

\author{
Rachyu Purbowati ${ }^{1}$, Suluh Agus Hendrawan ${ }^{2}$ \\ 1,2 Program Studi Akuntansi, STIE PGRI Dewantara Jombang, Indonesia \\ e-mail: rachyu.dewantara@gmail.com
}

$\begin{array}{ll}\text { Article Info: } \\ \text { Receive } & \text { : April } 2018 \\ \text { Revised } & : \text { Mei } 2018 \\ \text { Accepted } & : \text { Juni } 2018 \\ \text { Published } & : \text { Juni } 2018 \\ \text { DOI } & : \text { 10.21067/mbr.v2i1.4612 } \\ \text { Copyright } & : \text { Management and } \\ & \text { Business Review }\end{array}$

Keywords:

Kredit macet, faktor internal dan eksternal

\begin{abstract}
This study aims to determine the internal and external factors that cause bad credit. This study uses a qualitative descriptive approach that aims to analyze bad credit using internal and external factors. In this study using primary data and secondary data. The results show that the analysis of bad credit has more supervision from the manager and less thorough performance of all employees, and there are still multiple positions that do not match the job description. This can be seen from internal factors caused, among others, inadequate human resources, low ability to analyze credit applications, weak information systems and supervision and credit administration, interference in credit decisions, inability in management, loan interest rates., loan term, sales stability, and commitment of cooperative members to the agreement agreed by both parties. Meanwhile, external factors are caused by failure or disaster that befell the customer or the cooperative, bad faith on the part of the customer, credit loans without the knowledge of family or relatives, credit abuse by the customer.
\end{abstract}

Abstrak: Penelitian bertujuan untuk mengetahui faktor internal dan eksternal penyebab kredit macet. Penelitian ini menggunakan pendekatan deskriptif kualitatif, menggunakan data primer dan data sekunder. Hasil yang diperoleh bahwa analisis kredit macet disebabkan kurangnya pengawasan pihak manajer kurang telitinya kinerja dari semua karyawan, serta masih adanya rangkap jabatan yang tidak sesuai dengan job description. Penyebab faktor internal disebabkan oleh sumber daya manusia yang kurang kompeten, lemahnya sistem informasi dan pengawasan serta administrasi kredit, adanya campur tangan dalam keputusan kredit, ketidakmampuan dalam manajemen, suku bunga pinjaman, jangka waktu pinjaman, stabilitas penjualan, dan komitmen anggota koperasi pada perjanjian yang telah disepakati kedua belah pihak. Sedangkan faktor eksternal disebabkan karena adanya kegagalan atau musibah yang menimpa nasabah atau pihak koperasi, adanya itikad tidak baik dari pihak nasabah, adanya pinjaman kredit tanpa sepengetahuan pihak keluarga atau kerabat, adanya penyalahgunaan kredit oleh nasabah. 


\section{Pendahuluan}

Modal mendukung jalannya kegiatan perekonomian, salah satu bentuk usaha penyedia dana selain bank adalah Koperasi Simpan Pinjam. Perkembangan koperasi sangat dipengaruhi oleh banyaknya debitur yang dimiliki, sehingga apabila dari tahun ketahun koperasi memiliki peningkatan dalam keanggotaannya maka dapat dikatakan bahwa koperasi tersebut mengalami kemajuan yang baik. Sebaliknya jika debitur dalam suatu koperasi tersebut mengalami penurunan dari tahun ketahun maka dapat dikatakan juga bahwa koperasi tersebut mengalami penurunan. Begitu pula dengan tingkat keuntungan yang ada pada koperasi, semakin banyak debitur maka tingkat keuntungan pada koperasi otomatis mengalami peningkatan dan jika debitur berkurang maka keuntungan yang akan diperoleh menurun. Di samping itu banyaknya keanggotaan yang dimiliki belum tentu bisa menjamin tingkat kelangsungan koperasi dalam mencapai keuntungan. Pemberian kredit merupakan suatu bentuk badan usaha yang dilakukan oleh koperasi untuk mengelola modal yang dimiliki dari hasil donasi maupun simpanan anggota untuk memberikan suatu pinjaman kepada anggota dengan mengambil sebuah keuntungan dari pembayaran bunga dari angsuran koperasi yang dilakukan oleh para anggota.

Setiap orang berhak untuk bisa menjadi anggota koperasi simpan pinjam. Dalam keanggotaannya sendiri koperasi memiliki sifat sukarela dan sifat terbuka, dalam sifat kesukarelaan dalam keanggotaan koperasi mengandung makna bahwa menjadi anggota koperasi tidak boleh adanya paksaan dari pihak manapun. Seorang anggota koperasi dapat mengundurkan diri sesuai dengan syarat dan ketentuan yang sudah ada dalam anggaran dasar koperasi. Sedangkan untuk sifat terbuka memiliki arti bahwa dalam keanggotaan tidak dilakukan sebuah pembatasan ataupun diskriminasi dalam bentuk apapun (Abdurrahman, 2010).

Dilihat secara garis besar saat ini peluang dan kebutuhan ekonomi pada koperasi simpan pinjam lebih mudah jangkauannya dan lebih cepat dalam proses pencairan pinjaman dibandingkan dengan lembaga pembiayaan lainnya. Dari kemudahan dalam persyaratan pemberian kredit membuat koperasi simpan pinjam banyak diminati dari semua kalangan.

Pada koperasi simpan pinjam, sering kali terjadi masalah seperti kredit bermasalah atau macet. Kredit macet ini menggambarkan suatu situasi dimana persetujuan pengembalian kredit mengalami risiko kegagalan bahkan cenderung bisa mengalami kerugian atau modal tidak kembali. Oleh sebab itu perlu untuk diketahui terlebih dahulu sebab-sebab timbulnya kredit bermasalah bagi lembaga pembiayaan sebelum mencari alternatif pengelolaannya.

Kredit didefinisikan sebagai penyedia uang atau tagihan yang dapat dipersamakan berdasarkan persetujuan atau kesepakatan pinjam meminjam antara koperasi, bank maupun lembaga pembiayaan lainnya yang mewajibkan pihak 
peminjam atau kreditur untuk melunasi hutangnya setelah jangka waktu tertentu dan sesuai jatuh temponya dengan pemberian bunga. Dengan maksud agar setiap para anggota dapat bertanggung jawab atas kewajibannya. Hal inilah yang harus diperhatikan koperasi dimana dalam memberikan sebuah pinjaman atau kredit kepada para anggotanya harus memperhatikan faktor-faktor yang meyakinkan dalam pemberian kredit untuk bisa memastikan kelancaran dalam pembayaran kredit yang dilakukan oleh para anggota koperasi. Di sisi lain hal ini juga perlu dilakukan untuk mencegah terjadinya kredit macet yang bisa mengganggu jalannya suatu usaha dalam koperasi dan juga merugikan koperasi terutama dalam pencapain keuntungannya (Kasmir, 2014).

Kredit macet dan permasalahan yang selalu timbul merupakan risiko dari sebuah usaha untuk mendapatkan kredit. Timbulnya kredit macet sendiri disebabkan oleh para anggota yang tidak mau membayar kewajibannya karena adanya faktor-faktor yang mempengaruhinya. Faktor-faktor ini antara lain ada faktor internal atau di dalam dan faktor eksternal atau di luar lingkungan. Menurut Pratama et al. (2015), faktor internal meliputi sumber daya manusia (petugas/karyawan), rendahnya kemampuan pihak koperasi dalam melakukan ananlisis permohonan kredit, lemahnya sistem informasi dan pengawasan serta administrasi kredit, adanya campur tangan dalam keputusan kredit, ketidakmampuan dalam manajemen, suku bunga pinjaman, jangka waktu pinjaman, stabilitas penjualan, dan komitmen anggota koperasi pada perjanjian yang telah disepakati kedua belah pihak. Sedangkan dari faktor eksternal meliputi adanya kegagalan musibah yang menimpa nasabah atau pihak koperasi, adanya itikad tidak baik dari pihak nasabah, adanya pinjaman kredit tanpa sepengetahuan pihak keluarga atau kerabat, adanya penyalahgunaan kredit oleh nasabah. Tujuan dari pelaksanaan penelitian ini adalah untuk mengetahui bagaimana kredit macet pada Koperasi simpan pinjam.

\section{Pengertian Koperasi}

Koperasi adalah suatu bentuk kerja sama dalam perekonomian, kerja sama ini diadakan oleh sekumpulan orang karena adanya kesamaan jenis kebutuhan hidup mereka. Orang-orang ini bersama mengusahakan kebutuhan sehari-hari, kebutuhan yang bertalian dengan perusahaan ataupun rumah tangga mereka. Untuk mencapai tujuan itu diperlukan adanya kerja sama yang akan berlangsung terus, oleh sebab itu dibentuklah suatu perkumpulan sebagai bentuk kerja sama itu.

Koperasi Kredit atau Koperasi Simpan Pinjam menurut Anoraga (2007), didirikannya untuk memberikan sebuah kesempatan bagi para anggotanya untuk bisa memperoleh pinjaman dengan mudah dan ongkos (bunga) yang ringan dibandingkan dengan lembaga pembiayaan lainnya. Akan tetapi untuk dapat memberikan suatu pinjaman atau kredit, koperasi memerlukan sebuah modal yang tidak kecil. Modal dari koperasi yang utama adalah simpanan yang didapatkan dari anggotanya sendiri. Uang simpanan yang dikumpulkan secara bersama-sama 
kemudian diberikan kepada anggota yang perlu dibantu atau membutuhkan dana. Oleh karena itu, maka Koperasi Kredit lebih tepat disebut dengan Koperasi Simpan Pinjam.

\section{Kredit Macet}

Menurut Syafriansyah (2015), kata kredit berasal dari bahasa latin yaitu "credere" yang berarti percaya atau to believe atau to trust. Oleh karena itu, dasar pemberian persetujuan pemberian kredit oleh bank atau koperasi atau lembaga pembiayaan lainnya pada seseorang atau badan usaha adalah kepercayaan. Bila dikaitan dengan kegiatan usaha, kredit berarti suatu kegiatan yang memberikan nilai ekonomi (economic value) kepada seorang atau badan usaha yang berlandaskan sebuah kepercayaan, bahwa nilai ekonomi yang sama dikembalikan pada kreditur setelah jangka waktu sesuai dengan kesepakatan yang sudah disetujui antara kreditur dan debitur.

Kredit berasal dari kata credere (bahasa Yunani) yang artinya kepercayaan. Pengertian ini bermakna bahwa kegiatan kredit harus didasarkan pada kepercayaan (Taswan, 2006). Menurut Hasibuan (2008), kredit adalah semua jenis pinjaman yang harus dibayar kembali beserta bunganya oleh peminjam atau pihak debitur sesuai dengan perjanjian yang telah disepakati bersama di awal.

Penelitian Noorhayati (2010) menjelaskan bahwa penyebab kredit bermasalah karena faktor internal yaitu kebijakan perkreditan yang kurang menunjang, kelemahan dalam penilaian kredit, pengawasan yang kurang, dan itikad yang kurang baik dari pemilik, pengurus, dan pegawai bank. Sedangkan faktor eksternal karena adanya kesengajaan dari pihak nasabah. Penelitian Rani ( 2017) menjelaskan bahwa faktor-fakror yang berpengaruh terhadap kredit macet pada Koperasi adalah margin dan komitmen anggota koperasi, sedangkan jangka waktu pinjaman dan stabilitas penjualan tidak mempengaruhi kredit macet. Sedangkan Rahmawati (2015) menjelaskan bahwa kredit macet pada koperasi dipengaruhi oleh karakter, kemampuan, modal, dan kondisi. Sucipto (2015) menyatakan bahwa belum ada upaya efektif mengurangi kredit macet pada koperasi karena koperasi belum memiliki analisis kredit yang handal seperti pada bidang perbankan. Hasil penelitian Suarjaya et al. (2015) menyatakan terjadinya kredit macet pada Koperasi disebabkan faktor intern dan ekstern. Faktor intern meliputi kurang selektifnya dalam pemberian kredit, itikad tidak baik dari petugas Koperasi, serta lemahnya sistem pengawasan kredit. Adapun faktor ekstern meliputi kondisi perekonomian, itikad tidak baik dari debitur, atau terjadinya bencana alam. Utami et al. (2014) menyatakan penyebab kredit macet di koperasi di antaranya kebangkrutan yang dialami debitur, tingkat kemampuan melakukan pembayaran berkurang, dan adanya masalah keluarga. 


\section{Metode}

Peneliti menggunakan metode deskriptif kualitatif yaitu penelitian yang dilakukan untuk memahami realitas sosial dengan mengumpulkan data, mencari fakta, kemudian menjelaskan dan menganalisis data yaitu dengan cara pengumpulan dan penyusunan data, yang selanjutnya akan di analisis dan diinterpretasikan berdasarkan landasan teori yang ada. Tempat penelitian ini dilakukan di Koperasi Simpan Pinjam Karya Putra Jombang, Dalam penelitian ini, pengambilan data primer dilakukan dengan observasi atau pengamatan.

Dalam pengumpulan data ini peneliti menggunakan merode survey meliputi wawancara dengan bagian yang berhubungan dengan objek penelitian. Wawancara dilakukan dimaksudkan untuk mendapatkan gambaran yang lengkap tentang keadaan dan kenyataan yang sedang berlangsung baik mengenai data-data keuangan yang peneliti perlukan maupun program-program yang sedang berlangsung dan sudah dilaksanakan di unit Koperasi. Wawancara dilakukan secara face to face. teknik analisis data yang digunakan yaitu model Miles dan Huberman melalui triangulasi.

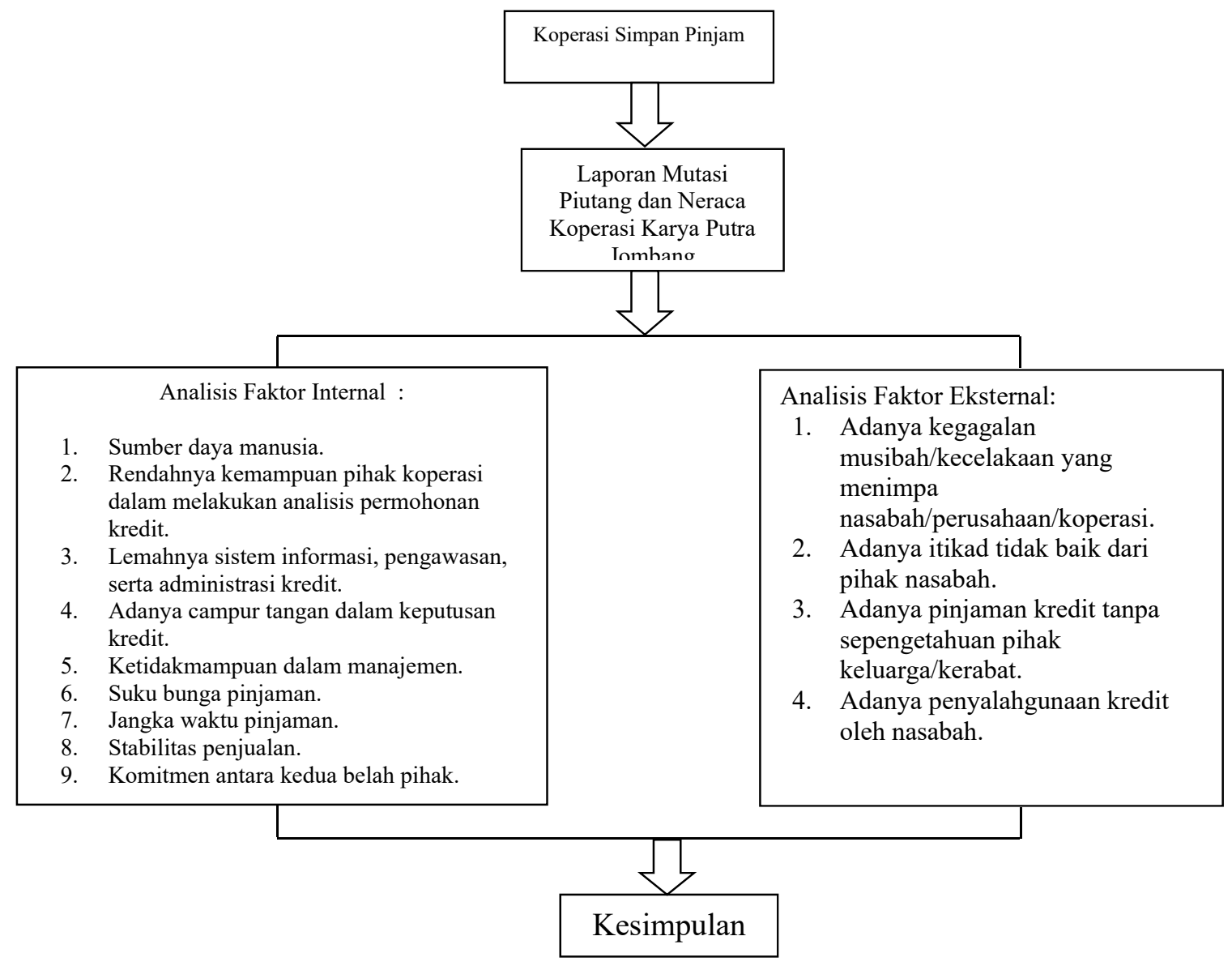




\section{Hasil}

\section{Faktor Internal pada Koperasi Karya Putra Jombang}

Faktor internal yang ada pada Koperasi Karya Putra Jombang mempengaruhi kredit macet adalah sebagai berikut:

\section{Sumber Daya Manusia (petugas atau karyawan)}

Merupakan suatu unsur utama dalam sebuah organisasi adalah manusia, maka hal terpenting yang perlu dilakukan pengelolaan sumber daya manusia yang baik. Dalam organisasi atau perusahaan akan menempatkan sumber daya manusia sebagai sesuatu yang berharga untuk dikelola dan dikembangkan. Dalam pengelolaan sumber daya manusia pada Koperasi Karya Putra Jombang dapat dilihat dari kinerja setiap masing-masing karyawan yang bekerja tidak sesuai dengan job description atau rangkap jabatan pada karyawan lainnya. Kondisi seperti ini yang menyebabkan ketidakfokusan terhadap pengelolaan koperasi.

Sehingga hal yang perlu dilakukan koperasi Karya Putra Jombang yaitu pengarahan kepada seluruh karyawan agar selalu berpartisipasi, dimana dalam partisipasi ini merupakan faktor penting dalam mendukung perkembangan koperasi agar berjalan dengan baik, dapat bekerja secara efisien, dan efektif dalam meningkatkan kesejahteraannya.Hal ini didukung dari hasil wawancara bagian manajer koperasi Karya Putra Jombang yang bernama Bpk. Kodrat Wahyudi Herry S. SIP yang menyatakan bahwa : "Penerapan sumber daya manusia dilakukan dalam mendayagunakan karyawan secara profesional yang diharapkan dapat memaksimalkan upaya untuk mensejahterakan semua karyawan sehingga dapat mengoptimalkan kinerja dalam melaksanakan job description dengan baik, efektif, maupun efisien". 'Hal ini didukung dari hasil wawancara bagian staf kredit koperasi Karya Putra Jombang yang bernama Lina Kristina yang menyatakan bahwa: "Solusi yang perlu dilakukan yaitu dengan melakukan sebuah pengarahan tentang koperasi kepada semua karyawan koperasi karya putra jombang (supervisor,collector, marketing, accounting, kasir, staf administrasi piutang, staf piutang, staf kredit) melalui diskusi atau musyarah yang dilakukan oleh manajer Bpk. Kodrat Wahyudi agar dapat berpartisipasi. Karena partisipasi dalam suatu organisasi maupun koperasi merupakan faktor penting dalam mendukung perkembangan untuk bisa meningkatkan rasa tanggung jawab sehingga setiap karyawan dapat bekerja secara efisien dan efektif". "1) Koperasi Karya Putra Jombang mulai sekarang harus memperhatikan dan mengadakan evaluasi untuk bisa melihat setiap perkembangan. 2) Sebaiknya membuka lowongan pekerjaan untuk menambah jumlah karyawan, dan saat akan mengadakan seleksi terhadap calon karyawan yang akan diterima

pihak koperasi juga harus menyelenggarakan secara sungguh-sunguh sehingga tidak begitu saja langsung menerima calon karyawan". 
Management and Business Review, 2(1) 2018, 1-15

\section{Rendahnya kemampuan pihak koperasi dalam melakukan analisis kredit}

Rendahnya kemampuan koperasi Karya Putra Jombang saat melakukan analisis kelayakan permohonan kredit yang akan diajukan oleh debitur/calon nasabah disebabkan karena permasalahan yang muncul, seperti belum efektifnya proses dan kinerja karyawan koperasi saat melakukan proses permohonan kredit, dan perlunya evaluasi karyawan yang dilakukan oleh atasan/manager untuk mengontrol kinerja setiap karyawan. Oleh sebab itu, saat ini yang diperlukan untuk memberdayakan koperasi Karya Putra Jombang dengan adanya sebuah komitmen yang kuat dan upaya-upaya dalam menangani, melayani, maupun saat proses permintaan kredit agar sesuai prosedur yang ada.

Hal ini didukung hasil wawancara bagian manajer koperasi Karya Putra Jombang yang bernama Bpk. Kodrat Wahyudi Herry S. SIP yang menyatakan bahwa:

“Analisa kredit 5C perlu dilakukan dalam sebuah koperasi simpan pinjam karena untuk mengurangi rendahnya kemampuan para karyawan dalam melakukan kinerjanya dan tujuan utamanya sendiri untuk memperoleh keyakinan apakah nasabah memenuhi kewajibannya kepada pihak koperasi secara tertib, baik pembayaran pokok pinjaman maupun bunga sesuai jatuh tempo dan kesepakatan bersama. Hal-hal yang perlu untuk diperhatikan dalam penyelesaian kredit pada nasabah, terlebih dahulu harus terpenuhinya prinsip 5C, antara lain" : 1) Character (watak), yang dimiliki oleh calon nasabah harus baik, jujur, dan bertanggungjawab. 2) Capital (jumlah dana / modal sendiri yang dimiliki nasabah). 3) Capacity (kemampuan yang dimiliki nasabah), untuk membayar kewajibannya. 4) Collateral (calon nasabah memiliki jaminan / agunan), yang menjadi jaminan harus unit yang jelas bukan curian. 5) Condition (situasi dan kondisi politik, ekonomi, sosial, dan budaya yang dimiliki calon nasabah).

Hal ini didukung dari hasil wawancara bagian staf kredit koperasi Karya Putra Jombang yang bernama Lina Kristina yang menyatakan bahwa :

"Sebaiknya bila ada nasabah yang tidak baik ataupun kurang mampu menerima penjelasan saat sedang berinterkasi, tetap memberikan pelayanan dengan baik, ramah, sopan dan menjelaskan nya lagi supaya bisa diterima baik oleh calon nasabah. Karena koperasi sendiri tujuan nya ingin mensejahterakan anggotanya".

Hal ini didukung dari hasil wawancara bagian staf krasir koperasi Karya Putra Jombang yang bernama Lilis Setiawati yang menyatakan bahwa :

"Memberi penjelasan secara baik-baik kepada calon nasabah untuk membawa datadata yang diperlukan dalam proses permohonan kredit untuk melengkapinya. Karena data yang dibawah oleh calon nasabah dalam koperasi Karya Putra Jombang harus benar-benar data yang asli (tidak foto copyan) agar mudah untuk menilai nantinya layak dan tidaknya calon nasabah dalam permohonan kredit". 
Management and Business Review, 2(1) 2018, 1-15

Lemahnya sistem informasi dan pengawasan serta administrasi kredit.

Sistem informasi merupakan kombinasi dari teknologi informasi dan aktivitas para karyawan koperasi yang menggunakan teknologi untuk mendukung operasi dan manajemen koperasi Karya Putra Jombang agar lebih efektif untuk mencapai suatu tujuan. Sedangkan dalam pengawasan yang dilakukan harus selektif untuk bisa melihat sejauh mana perkembangan yang ada pada koperasi baik dari pendapatan dan kinerja setiap karyawan. Dalam administrasi yang dilakukan oleh staf kasir sangat penting dimana ketika staf kredit akan melakukan pencairan dana per hari harus sesuai dengan kas yang ada agar tidak melebihi kuota yang tersedia sehingga pemasukan dan pengeluaran akan balance.

Hal ini didukung dari hasil wawancara bagian staf administrasi collector koperasi Karya Putra Jombang yang bernama Komsiah yang menyatakan bahwa: "Kelemahan yang masih terjadi dalam sistem informasi yang saat ini sedang berjalan yaitu pada sistem program komputer, dimana masih belum ada sistem validasi dari masing-masing kantor cabang. Karena hanya kantor pusat saja yang menggunakan sistem komputer dengan menggunakan program server yang secara otomatis tinggal memasukan data dengan menginputnya ke dalam program kredit. Hal ini yang membuat dalam penyampaian sistem informasi menjadi lambat ketika laporan dari kantor cabang akan disetorkan ke kantor pusat harus menunggu terlebih dahulu, terjadi misscomunication antara staf collector, staf administrasi piutang, staf administrasi collector, dan kasir, dan kurang telitinya pencatatan yang dilakukan staf administrasi collector karena masih manual nya sistem yang digunakan dari masing-masing kantor cabang".

Hal ini didukung dari hasil wawancara bagian staf accounting koperasi Karya Putra Jombang yang bernama Elwis Gladys yang menyatakan bahwa: "Dalam pengawasan yang dilakukan manajer koperasi Bpk. Kodrat Wahyudi bisa dikatakan cukup baik, karena masih ada pengawasan yang kurang teliti dalam kinerja para karyawan, misalnya saat melakukan pencatatan kwitansi sering terjadi kesalahan dalam penulisan".

Hal ini didukung dari hasil wawancara bagian staf kasir koperasi Karya Putra Jombang yang bernama Lilis Setiawati yang menyatakan bahwa: "Dalam administrasi kredit yang masih sering terjadi, yaitu saat akan mengeluarkan dana pencairan terkadang masih melebihi kuota/kas yang sudah disediakan, karena staf kredit sendiri terkadang kalau kuota pencairan sudah habis masih menerima pengajuan calon nasabah karena adanya beberapa faktor lain yang membuat menerima pencairan tersebut".

\section{Adanya campur tangan dalam keputusan kredit.}

Dalam permohonan kredit kepada calon nasabah pihak koperasi harus mengikuti prosedur yang sudah diberikan untuk dijalankan sebagai syarat permohonan kredit calon nasabah. Kenyataan yang terjadi pemilik koperasi atau ketua memberikan fasilitas kredit kepada calon nasabah atas dasar kekerabatan, sehingga 
mengesampingkan aturan aturan prosedur yang berlaku pada Koperasi Karya Putra Jombang. Hal ini didukung dari hasil wawancara bagian supervisor koperasi Karya Putra Jombang yang bernama Joharul yang menyatakan bahwa: "Sebaiknya pemilik koperasi Bpk. Halim Sutjahjo dan karyawan koperasi tetap memberlakukan prosedur yang sudah berlaku untuk menghindari hal yang tidak di inginkan dari kedua belah pihak, dan menghidari risiko terjadinya kredit macet untuk kedepannya".

\section{Ketidakmampuan dalam manajemen}

Dalam koperasi Karya Putra Jombang ketidakmampuan dalam manajemen terjadi pada pengolahan dana saat pencairan kredit uang yang dikeluarkan terkadang tidak sesuai dengan kuota yang tersedia dan pengawasan yang kurang baik / teliti terhadap semua karyawan (kasir, staf kredit, staf administrasi piutang, staf administrasi collector, supervisor, collector, marketing, dan accounting) dari pihak manajer. Hal ini didukung dari wawancara bagian makelar koperasi Karya Putra Jombang yang bernama David yang menyatakan bahwa : "Bila pengawasan kredit kurang baik akan menyebabkan kelemahan kredit dan menimbulkan kelalaian dari para karyawan sehingga saat manajer akan meminta data ke karyawan, data yang akan didapatkan tidak akurat".'

Suku bunga pinjaman. Suku bunga pinjaman dalam koperasi Karya Putra Jombang merupakan biaya yang dibebankan kepada setiap nasabah yang mengembalikan kredit atau pinjaman, dimana suku bunga tersebut sedah ditentukan oleh pihak koperasi yang disesuaikan dengan kondisi pinjaman nasabah.

Hal ini didukung dari wawancara bagian administrasi collector koperasi Karya Putra Jombang yang bernama Komsiah yang menyatakan bahwa: "Yang mempengaruhi dalam menetapkan besar kecilnya suku bunga pada koperasi karya putra Jombang, yaitu : 1) Jangka waktu, apabila jangka waktu kredit yang diberikan oleh koperasi Karya Putra Jombang dengan rentang waktu yang panjang kepada calon nasabah maka makin tinggi risiko yang mungkin muncul dalam pembayaran angsuran nantinya. 2) Kualitas jaminan kredit yang diajukan oleh calon nasabah. Bila calon nasabah memberikan jaminan untuk pengajuan kredit mempunyai kualitas atau harga jual yang tinggi, maka dana yang akan dicairkan nilainya tinggi sesuai dengan yang akan dijaminkan. Sehingga risiko kredit yang muncul kemungkinan rendah".

\section{Jangka waktu atau tenor pinjaman}

Rentang waktu yang diberikan oleh pihak koperasi kepada calon nasabah dalam pinjaman kredit sesuai dengan kemampuan dalam membayar angsuran, agar melakukan kewajibannya sesuai dengan jatuh tempo pembayaran. Hal ini didukung dari hasil wawancara bagian staf kasir koperasi Karya Putra Jombang yang bernama Lilis Setiawati yang menyatakan bahwa : 
“Bila nasabah membayar angsuran tidak sesuai jatuh temponya (tidak lebih dari 3 bulan) bisa melakukan pembayaran angsuran beserta denda, tapi bila nasabah pembayaran angsuran telat melebihi 3 dan 5 bulan maka ada tindakan dari pihak collector".

Hal ini didukung dari hasil wawancara bagian collecor koperasi Karya Putra Jombang yang bernama Rudi Kurniawan yang menyatakan bahwa : 1) Melakukan pengendalian kredit macet terlebih dahulu dengan cara mencatat kembali mengenai data atau identitas debitur mulai dari alamat, jumlah pinjaman, pokok beserta bunga pinjaman, jangka waktu pinjaman, tanggal pengajuan pinjaman, pembayaran angsuran, dan perjanjian kredit. Tujuan supaya bisa mengetahui apakah nasabah bisa mengembalikan kreditnya sesuai dengan kesepakatan yang sudah ada dalam perjanjian. 2) Mengadakan pendekatan kepada debitur dengan melakukan komunikasi baik secara lisan ataupun lewat telefon. Jika dalam tahap ini debitur hanya merespon tanpa adanya itikad untuk melunasi hutangnya, maka tahap pemberian SP (Surat Peringatan) ataupun teguran kepada nasabah menjadi tahap selanjutnya yang akan dilakukan. 3) Jika sebagian atau seluruh tahap yang sudah dilakukan tidak dapat dipenuhi oleh debitur sesuai dengan perjanjian kredit dan persyaratan yang ada, maka akan ada tindakan lain dengan prosedur sebagai berikut : 1) Memberikan surat teguran peringatan ke-I langsung kepada debitur. Penjelasan akan disampaikan kepada debitur akibat dari keterlambatan dalam pokok pinjaman dan bunga pinjaman.2) Jika butir a tidak dipenuhi oleh pihak debitur, akan menindaklanjuti debitur dengan memberikan surat peringatan atau teguran yang ke-II dengan isi surat tersebut tentang pembayaran yang harus dilunasi dengan tebusan yang sama sesuai dengan pinjaman kredit. 3) Jika surta keII, debitur tidak menunjukkan itikad untuk melunasi pinjamannya, maka pihak koperasi sendiri akan memanggil dengan surat ke-III yang akan ditunjukkan pada debitur dengan tembusan dari manajer koperasi Bpk. Kodrat Wahyudi. 4) Mendatangi langsung debitur jika surat ke-III debitur tidak datang untuk melunasi seluruh pinjamannya, maka akan mendata kembali secara detail untuk mengidentifikasi masalah yang ada pada nasabah dan menyelesaikan untuk keputusan terakhir sebelum unit yang dijaminkan bisa ditarik. "'

\section{Stabilitas Penjualan}

Tingkat kelancaran penjualan kredit pada koperasi Karya Putra Jombang yang dilakukan pihak koperasi dalam pencairan pinjaman setiap harinya agar sesuai dengan pemasukan (kas yang tersedia). Hal ini didukung dari hasil wawancara bagian staf kasir koperasi Karya Putra Jombang yang bernama Lilis Setiawati menyatakan bahwa: " Pengeluaran dana yang diberikan untuk pencairan pinjaman kepada nasabah terkadang tidak sesuai dengan dana atau kas yang ada memang benar. Karena terkadang ketika kuota pinjaman sudah ditutup masih ada beberapa calon nasabah yang melakukan pinjaman diterima oleh staf kredit yang bernama Lina Kristina karena ada alasan tertentu seperti calon nasabah lagi butuh dana 
mendadak disaat itu juga atau ada alasan tertentu. " Hal ini dari hasil wawancara bagian collector koperasi Karya Putra Jombang yang bernama Adi Sukamto yang menyatakan bahwa: "Dapat mengurangi tingkat penjualan pihak koperasi memang benar, karena nasabah tidak lancar merupakan salah satu faktor penyebab dimana kredit dapat dikatakan bermasalah dan memiliki risiko tinggi, karena debitur telah gagal dalam mengembalikan hutangnya".

Komitmen anggota koperasi.

Suatu perjanjian yang telah dilakukan antara kedua belah pihak yaitu dari pihak calon nasabah dan staf kredit yang bernama Lina Kristina tanpa adanya suatu paksaan sebelum memberikan suatu pinjaman kredit yang sudah disepakati bersama. Agar kedua belah pihak sama-sama jujur dan bertanggungjawab atas kesepakatn yang sudah dilakukan untuk menghindari hal-hal yang tidak diinginkan dari masing-masing pihak. Hal ini didukung dari hasil wawancara bagian staf kredit Koperasi Karya Putra Jombang yang bernama Lina Kristina menyatakan bahwa :

"Adanya unsur kesepakatan yang harus terpenuhi dari pihak calon nasabah yaitu kepercayaan dan kejujuran".

\section{Faktor Eksternal pada Koperasi Karya Putra Jombang}

Faktor eksternal yang dihadapi koperasi Karya Putra Jombang adalah sebagai berikut:

\section{Adanya kegagalan musibah atau kecelakaan yang menimpa nasabah/perusahaan}

Pada koperasi Karya Putra Jombang bila ada nasabah yang mengalami suatu musibah atau kecelakaan seperti kematian pada saat sedang dalam proses angsuran koperasi, maka akan diberi suatu keringan bagi pihak keluarga dalam proses pembayaran jika akan melunasi hutangnya. Hal seperti ini membuat pihak koperasi menjadi rugi bila nasabah masih dalam tunggakan kredit / telat berbulan-bulan dan pokok pinjaman dalam jumlah banyak, karena menyebabkan pendapatan pihak koperasi menjadi berkurang yang disebabkan oleh tanggungan beban. Hal ini didukung dari hasil wawancara bagian manajer koperasi Karya Putra Jombang yang bernama Bpk. Kodrat Wahyudi Herry S. SIP yang menyatakan bahwa: "Bila nasabah mengalami musibah seperti kematian, koperasi akan memberikan suatu deviasi atau keringanan kepada pihak keluarga dengan prosentase yang dilihat berdasarkan seberapa banyak jumlah pokok dan bunga pinjaman yang tersisa".

Adanya itikad tidak baik dari pihak nasabah. Dalam koperasi simpan pinjam Karya Putra Jombang, masih ada nasabah yang menyebabkan tidak lancarnya pembayaran kredit, misalnya pembayaran yang awalnya baik sesuai dengan jatuh tempo dan lancar, namun setelah bulan berikutnya nasabah tidak ada pembayaran / telat dengan melebihi jatuh tempo yang dilakukan terus-menerus dengan sengaja. Hal ini didukung dari hasil wawancara bagianstaf kasir koperasi Karya Putra Jombang yang bernama Lilis Setiawati yang menyatakan bahwa: "Sering sekali memperoleh nasabah yang tidak baik saat melakukan pembayaran angsuran seperti, tidak mau 
membayar denda ketika disuruh untuk membayar keterlambatan, minta potongan pembayaran ataupun pelunasan dengan tidak sopan, tidak mau antri saat membayar angsuran, tidak membawa kartu angsuran".

\section{Adanya pinjaman kredit tanpa sepengetahuan pihak keluarga / kerabat}

Saat melakukan pengajuan pinjaman kredit oleh nasabah dengan suatu jaminan tanpa sepengetahuan pihak keluarga / kerabat menyebabkan perselisihan yang bisa terjadi antar pihak keluarga dengan pihak koperasi, ketika collector akan melakukan sebuah kunjungi kerumah nasabah atau menagih kewajiban nasabah bila telat membayar. Pihak keluarga tidak mengetahui dan tidak bertanggungjawab bila ada hal-hal yang tidak diinginkan. Hal ini didukung dari hasil wawancara bagiancollector koperasi Karya Putra Jombang yang bernama Arief yang menyatakan bahwa: "Saat melakukan kunjungan kerumah nasabah akan memberikan suatu penjelesan kepada pihak keluarga bila pihak keluarga tidak mengetahui keluarganya ada yang memiliki pinjaman kredit di koperasi Karya Putra Jombang. Hal ini dilakukan untuk menghindari hal-hal yang tidak diinginkan dari kedua belah pihak dan pihak keluarga bisa bertanggungjawab bila terjadi hal yang tidak diinginkan".

\section{Adanya penyalahgunaan kredit oleh nasabah}

Pada koperasi Karya Putra Jombang masih ada calon nasabah yang melakukan suatu pinjaman kredit tidak sesuai dengan apa yang menjadi tujuan utama melakukan pinjaman, misalnya ketika di interview pertanyaan oleh staf kredit dana yang dipinjam untuk modal usaha, ternyata ketika di croscek lagi oleh collector dana pinjaman digunakan untuk menutup hutangnya di koperasi atau leasing lainnya. Dan dalam pengembalian pinjaman sering kali tidak lancar bahkan macet karena sering terjadi pinjaman yang tidak sesuai jangka waktu pinjaman. Hal ini didukung dari hasil wawancara bagian supervisor koperasi Karya Putra Jombang yang bernama Joniyanto yang menyatakan bahwa: "Manajer koperasi Bpk. Kodrat Wahyudi sendiri akan melakukan pengawasan lebih kepada staf kredit dalam melakukan proses pinjaman kredit. Supaya data yang akan diperoleh lebih akurat, jika suatu saat nanti akan mengecek nama-nama nasabah yang melakukan pinjaman".

\section{Pembahasan}

Sumber daya manusia (petugas/ karyawan) yang ada pada koperasi simpan pinjam Karya Putra Jombang belum bisa dikatakan baik, karena kurangnya karyawan yang membuat kinerja dari setiap devisi tidak sesuai dengan job description sehingga membuat kinerja setiap karyawan menjadi rangkap jabatan. Kondisi seperti inilah yang menyebabkan kinerja para karyawan menjadi tidak efektif. Rendahnya kemampuan pihak koperasi dalam melakukan permohonan kredit yang ada pada Koperasi Karya Putra Jombang bisa dikatakan cukup baik, 
dimana dalam manajemen pengelolaan dana yang dilakukan oleh staf kredit saat pencairan kredit uang yang dikeluarkan terkadang tidak sesuai dengan kuota yang tersedia. Lemahnya sistem informasi dan pengawasan serta administrasi kredit pada koperasi simpan pinjam Karya Putra Jombang belum bisa dikatakan baik, karena setiap kantor cabang belum menggunakan program server atau manual yang menghambat kinerja para karyawan, pengawasan yang dilakukan manajer koperasi masih kurang teliti, ini sering terjadi dalam pencatatan kwitansi sehingga membuat misscomunication antar staf administrasi collector dengan collector, dan administrasi yang dikeluarkan dalam pencairan dana setiap harinya tidak terkontrol dengan baik. Adanya campur tangan dalam keputusan kredit pada koperasi simpan pinjam Karya Putra Jombang masih sering terjadi terutama dari pemilik koperasi sendiri Bpk. Halim Sutjahjo, memberikan fasilitas kredit ketika ada kerabat yang akan melakukan pinjaman kredit dengan mengesampingkan prosedur atau aturan yang berlaku pada koperasi Karya Putra Jombang.

\section{Faktor Eksternal pada Koperasi Simpan Pinjam Karya Putra Jombang}

Adanya kegagalan musibah atau kecelakaan yang menimpa nasabah atau koperasi simpan pinjam Karya Putra Jombang, akan memberikan suatu keringanan atau toleransi kepada pihak keluarga apabila ada yang meninggal atau mengalami musibah dengan melihat prosentase berdasarkan jumlah pokok dan bunga kredit nasabah. Adanya itikad tidak baik dari pihak nasabah yang ada pada koperasi simpan pinjam Karya Putra Jombang masih sering terjadi terutama saat melakukan proses pembayaran angsuran dimana nasabah tidak membawa kartu angsuran, meminta potongan pelunasan maupun denda dengan tidak baik, saat pembayaran yang awalnya baik sesuai dengan jatuh tempo dan lancar tiba-tiba bulan berikutnya nasabah telat dan tidak membayar sampai berbulan-bulan, ketika melakukan pinjaman kredit tidak membawa data dengan lengkap.Adanya pinjaman kredit tanpa sepengetahuan pihak keluarga atau kerabat, sering dilakukan oleh nasabah koperasi simpan pinjam Karya Putra Jombang yang membuat perselisihan antar pihak keluarga dengan pihak koperasi terutama staf collector, ketika akan melakukan suatu kunjungan kerumah nasabah atau menagih pembayaran yang telat. Adanya penyalahgunaan kredit oleh nasabah yang ada pada koperasi simpan pinjam Karya Putra Jombang, masih ada beberapa nasabah yang nakal ketika melakukan pinjaman kredit uang yang akan digunakan tidak sesuai dengan hasil interview yang dilakukan oleh staf kredit, ketika akan di croscek.

\section{Simpulan}

Dari hasil pembahasan di atas diperoleh bahwa analisis kredit macet adanya pengawasan yang lebih lagi dari pihak manajer dan kurang telitinya kinerja dari semua karyawan, serta masih adanya rangkap jabatan yang tidak sesuai dengan job description masing-masing. Hal ini bisa dilihat dari faktor internal yang disebabkan 
dari pihak internal antara lain kurannya sumber daya manusia yang berkompeten, sehingga rendahnya kemampuan pihak dalam melakukan analisis permohonan kredit, lemahnya sistem informasi dan pengawasan serta administrasi kredit, adanya campur tangan dalam keputusan kredit, ketidak mampuan dalam manajemen, suku bunga pinjaman, jangka waktu pinjaman, stabilitas penjualan, dan komitmen anggota koperasi pada perjanjian yang telah disepakati kedua belah pihak. Sedangkan dari faktor eksternal disebabkan karena adanya kegagalan musibah yang menimpa nasabah atau pihak koperasi, adanya itikad tidak baik dari pihak nasabah, adanya pinjaman kredit tanpa sepengetahuan pihak keluarga atau kerabat, adanya penyalahgunaan kredit oleh nasabah.

\section{DAFTAR PUSTAKA}

Abdurrahman, Y. (2010). Tinjauan Kritis Seputar Koperasi. Al-Azhar Press, Bogor.

Anoraga, P. (2007). Dinamika Koperasi. Rineka Cipta.

Hasibuan, S. P. (2008). Dasar-Dasar Perbankan. Jakarta: Bumi Aksara.

Kasmir, S. (2014). Bank dan Lembaga Keuangan Lainnya. Edisi Revisi.

Noorhayati, E. S. (2010). Prosedur kredit dan upaya mengatasi kredit bermasalah pada PD. BPR BKK Jati Kudus. Diponegoro University.

Pratama, G. D. Y., Westra, I. K., \& Purwanti, N. P. (2015). Penyelesaian Kredit Macet Pada KSU Tumbuh Kembang Pemogan-Denpasar Selatan. Universitas Udayana.

Rahmawati, J. (2015). Analisis Faktor-Faktor Yang Mempengaruhi Kredit Bermasalah Pada KSP Bangun Jaya Cab. Wonogiri. Universitas Muhammadiyah Surakarta.

Rani, S. D. (2017). Analisis Faktor-Faktor yang Mempengaruhi Kredit Macet pada Koperasi Simpan Pinjam Pembiayaan Syariah Al-Anshari di Kota Bukittinggi (Didasarkan atas Persepsi Anggota Koperasi). Universitas Andalas.

Suarjaya, I. N., Cipta, W., \& Zukhri, A. (2015). Analisis Penyelesaian Kredit Macet Pada Koperasi Pasar Srinadi Klungkung. Jurnal Pendidikan Ekonomi Undiksha, $5(1)$.

Sucipto, A. (2015). Prediksi Kredit Macet Melalui Perilaku Nasabah Pada Koperasi Simpan Pinjam Dengan Menggunakan Metode Algoritma Klasifikasi C4. 5. Jurnal DISPROTEK, 6(1). 
Syafriansyah, M. (2015). Analisis Sistem Dan Prosedur Pemberian Kredit Pada Koperasi Simpan Pinjam Sentosa Di Samarinda. Ejournal Ilmu Administrasi Bisnis.

Taswan, C. (2006). Manajemen Perbankan, Konsep, Teknik dan Aplikasi. Yogyakarta: UPP STIM YKPN.

Utami, P. S., Zukhri, A., \& Cipta, W. (2014). Analisis Sistem Pengendalian Intern Dan Penanganan Kredit Macet Pada Koperasi Kredit Swastiastu Singaraja Tahun 2012. Jurnal Pendidikan Ekonomi Undiksha, 4(1). 